\title{
Analysis of filtration processes in small experimental embankment based on numerical modeling and temperature measurements
}

\author{
by B. Bukowska-Belniak*, K. Krawiec* , A. Leśniak and D. Kessler**
}

*AGH University of Science and Technology, al. Mickiewicza 30, 30-059 Krakow, Poland,

bukowska@agh.edu.pl,krzysiek.krawiec@agh.edu.pl, lesniak@agh.edu.pl

**NeoSentio Ltd., ul. Konfederacka 23, 30-306 Krakow, Poland, dk@neosentio.pl

\section{Abstract}

This paper presents analysis of filtration processes in small experimental embankment. The analysis is based on field measurements and numerical modeling. The measurements were performed on experimental embankment, which size is in scale 1:5 comparing to typical river embankments in Poland. The measurements are made during flooding experiment. Two parameters during experiment ware measured: pore pressure and temperature. Additionally, the thermograpical observation of air side of embankment was conducted. The FLAC 7.0 software was used in 2D numerical modeling. Modification the parameters of the model allowed to fit the modelled data to the measured data.

\section{Introduction}

The small experimental embankment was put up as a part of ISMOP project [1]. It was constructed by the NeoSentio company to investigate the influence of sensors installation for the filtration process and structure stability. Another goal was recognition of the thermal processes inside the soil embankment during flooding.

\section{Measurements}

The small experimental embankment is divided into four sections perpendicular to symmetry axis of the embankment. Sensors are located in piezometers in two central sections. The embankment consists of the following elements: an insulating layer, hydraulic trough of sheet steel, trapezoidal soil barrier, buttress filter, drainage system and piezometers system. The insulating layer is constructed of impermeable soil. Trapezoidal soil barrier is composed of clastic native soil. The buttress filter is made of a cell grid geoweb filled of soil with high permeability. The drainage system is constructed in buttress filter area.

The described measurements were made in mostly sunny day, air temperature was about $28-30^{\circ} \mathrm{C}$, there was no rain. The soil embankment was located in the shade, under a tent. The embankment was dry in the beginning of the experiment. The flooding and discharging process took about 6 hours. All sensors measure with timestamp 10 seconds.

Additionally the thermographical observation of air side of embankment was made [2]. Figure 1 presents thermal images registered during experiment. Thermal images highlight the relative temperature changes on the embankment's surface.
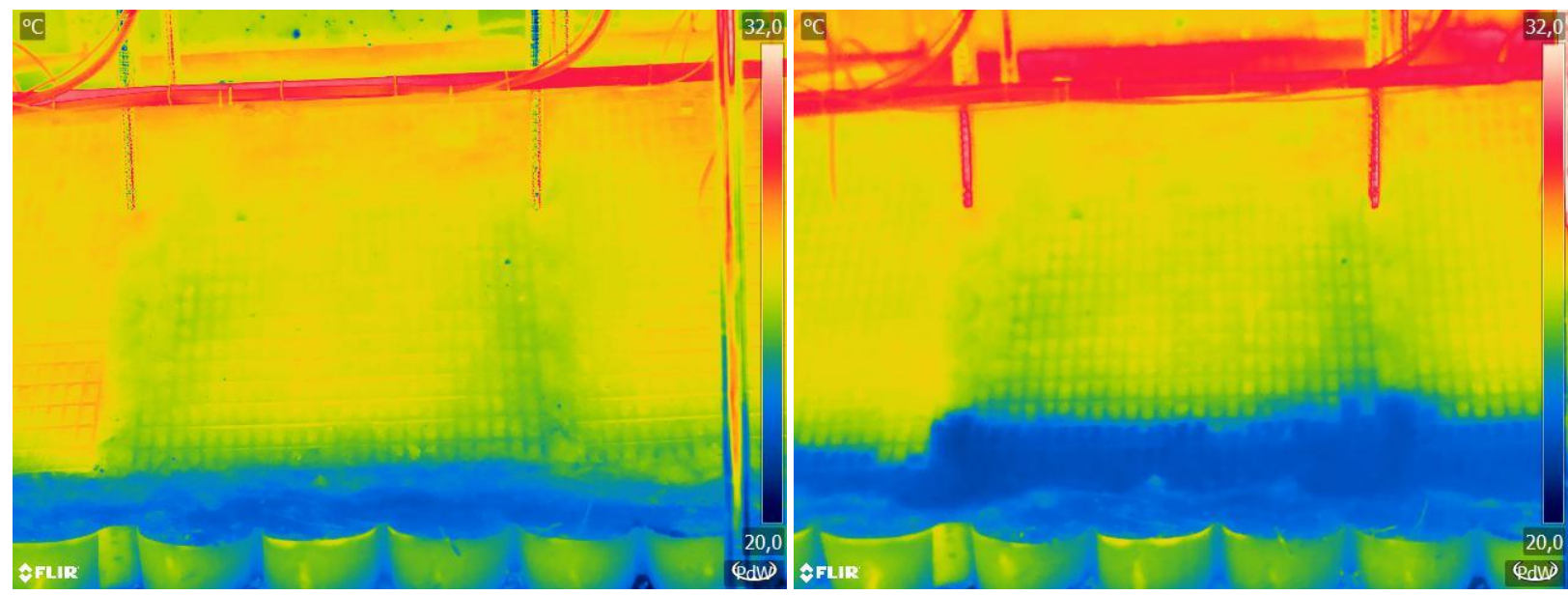

Fig. 1. Comparison of measured temperatures using infrared camera. Left image without leakage, right with water leakage. 


\subsection{1/qirt.2016.015}

\section{Modeling}

A 2D numerical modeling was performed in FLAC 7.0 software [3]. The model reflects the geometric and geotechnical attributes of the real embankment. Similar models were also created for experimental embankment in scale $1: 1$, built as a main aim of ISMOP project [4,5]. Figure 2 presents a comparison between water level measured by pore pressure sensors (red lines) and water level taken from numerical model (blue lines) in one embankment sector. Also comparison between measured and modelled temperatures was performed. The model quite well predicts the time when water reach each sensor. But there is a difference in the rate of fall of water level.

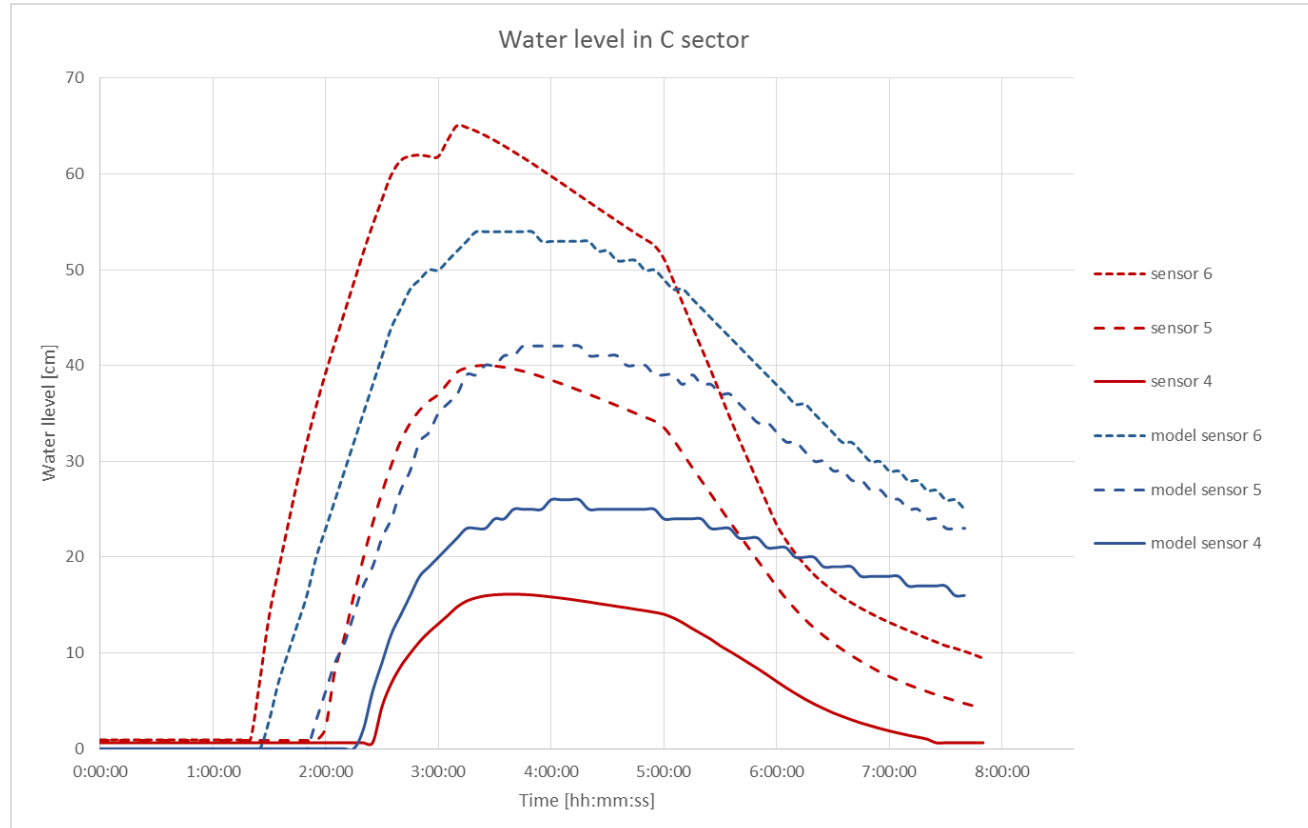

Fig. 2. Comparison of measured water level using pore pressure sensors and modeled values

\section{Conclusions}

Infiltration of the water caused changes of the soil temperature, which was measured by thermal sensors inside the embankment. Similarly the thermography allowed to observe the thermal changes on the embankment surface and reflects its dampness. Numerical modeling could be useful for prediction of the infiltration of the water through the embankment, when it is compared with pore pressure values changes registered in water level in embankment. It is important to calibrate the results of the modeling with real data which are measured by pore pressure sensors or thermal sensors. Modification of the soil parameters of the embankment's model allows to fit the modelled data to the measured values. In that way numerical modeling could help in determining of the values of real parameters of soil, especially when the geological and laboratory investigations are impossible or limited.

This work was supported by the National Centre of Research and Development (NCBiR), Poland, project PBS1/B9/18/2013 (no. 180535) [1]

This work was partly supported by the AGH University of Science and Technology, Faculty of Geology, Geophysics and Environmental Protection, as part of statutory project no. 11.11.140.613.

\section{REFERENCES}

[1] ISMOP - Computer System for Monitoring River Embankments (in Polish: Informatyczny System Monitorowania Obwalowań Przeciwpowodziowych), www.ismop.edu.pl.

[2] Bukowska-Belniak B., Leśniak A., Kessler D., "Thermographical monitoring of leak processes in embankments", AITA 2015,13th international workshop on Advanced Infrared Technology \& Applications: proceedings, pp. 76 78, 2015.

[3] FLAC, User's Manual, Itasca Consulting Group Inc. Minneapolis, 2007.

[4] Bukowska-Belniak B., Dwornik M., Pięta A., Leśniak A., "A 2D model of temperature changes in experimental embankment", Measurement, Automation, Monitoring, 2015 vol. 61 no. 6, pp. 233-236.

[5] Dwornik M., Krawiec K., Pięta A., Leśniak A., "Numerical and experimental stability analysis of earthen levees" Proceedings of the 17th annual conference of the International Association for Mathematical Geosciences, September 5-13, 2015, Freiberg (Saxony) Germany. 